\title{
LEVANTAMENTO DA PREVALÊNCIA DE RAIZ SUPRANUMERÁRIA EM CANINOS MANDIBULARES
}

Kaye Varaschin THEODOROVICZ, Antonio Adilson Soares de LIMA

Os dentes podem apresentar raízes acessórias ou supranumerárias. Esta anomalia pode estar relacionada a trauma, pressão ou doença metabólica que afete a bainha epitelial de Hertwig. Raízes supranumerárias podem ser completamente desenvolvidas em tamanho e forma ou pequenas e rudimentares. Muitas vezes, elas estão fusionadas a outras raízes, ou ainda podem ser bífidas e amplamente separadas. A presença de raízes supranumerárias é estabelecida por meio do exame radiográfico. Este estudo determinou a prevalência de raízes supranumerárias em caninos mandibulares numa população adulta jovem com relação ao sexo e a sua localização. Quatrocentos e vinte e oito levantamentos periapicais foram avaliados em ambiente escurecido, sobre negatoscópio e com uso de uma máscara para evitar o excesso de luminosidade. Os resultados revelaram que a prevalência de raízes supranumerárias foi de 11 casos (2,57\%) naquela população. Em relação ao sexo, a prevalência desta anomalia foi de oito casos em mulheres $(72,72 \%)$ e três em homens $(27,27 \%)$. Quanto a localização, quatro casos foram bilaterais $(36,36 \%)$ sendo todos em indivíduos do sexo feminino e sete casos unilaterais (5 no dente 43 e 2 no dente 33). Este estudo revelou que ocorrência de raízes supranumerárias em caninos é baixa e afeta mais no sexo feminino.

Palavras-chave: Raiz dentária; Dente canino; Prevalência; Diagnóstico. 